\title{
Moving out of the Attic: Susan Glaspell and the American She-Tragedy
}

\author{
Zaid Ibrahim Ismael ${ }^{1} \&$ Jinan Waheed Jassim ${ }^{2}$ \\ ${ }^{1}$ Department of English, Al-Mansour University College, Baghdad, Iraq \\ ${ }^{2}$ College of Arts, Mustansiriyah University, Baghdad, Iraq \\ Correspondence: Zaid Ibrahim Ismael, Department of English, Al-Mansour University College, Baghdad, Iraq.
}

\author{
Received: September 24, 2018 Accepted: October 20, 2018 Online Published: November 28, 2018 \\ doi:10.5539/ells.v8n4p1 URL: https://doi.org/10.5539/ells.v8n4p1
}

\begin{abstract}
Midwestern American dramatist Susan Glaspell (1876-1948) was one of the early voices in the American theater who explored gender issues and woman's rights at the beginning of the twentieth century. She portrays women in distress, trying to find an outlet from the vicious circle of loneliness and abuse in which they live. Despite the fact that her characters resist oppression and degradation and try to defy the patriarchal authority that restrains them, they are often overwhelmed by this powerful male-dominated system. As a result, they grow defensive and resort to violence and murder in order to avenge themselves from the society that dehumanizes them. They ultimately fall prey to their tragic fate, not necessarily death, but psychological disintegration and incarceration. Glaspell's tragic heroines are outsiders, living in a world that thwarts their dreams to have a free life beyond the prescribed roles and social demands of house management, domesticity, and social propriety. This study applies the feminist theory of Sandra M. Gilbert and Susan Gubar, introduced in their seminal work The Madwoman in the Attic, to two of Glaspell's major plays, namely Trifles and The Verge. It also aims at tracing the elements of the Restoration 'she-tragedy' in these plays to prove to what extent Glaspell is a master of this form of writing.
\end{abstract}

Keywords: feminist, Glaspell, madness, oppression, patriarchal, she-tragedy

\section{Introduction}

Susan Glaspell is often remembered for her role in establishing one of America's early influential theater companies, the Provincetown Players, which helped motivating prominent names in American theater history to write and produce their plays; the most important of them is Eugene O'Neill. She is also praised for her contribution to the development of the feminist movement at the beginning of the twentieth century. Commentators on her dramatic works focus on her experimental techniques, the development of her style, the social and cultural context of her plays, in addition to her feminist views.

This study is an attempt to put Glaspell's drama in the context of contemporary feminist theory, particularly Sandra M. Gilbert and Susan Gubar's psycho-feminist scholarship The Madwoman in the Attic (2000). Gilbert and Gubar focus on Charlotte Bronte's female victim in Jane Eyre, the mentally-ill Bertha Mason-Mr. Edward Rochester's wife - who is incarcerated in the attic of the house by her husband. This image contrasts the idealistic female title character, whose independent spirit, purity and moral integrity charm not only the hero but the sympathetic readers as well. The critics theorize that this stereotypical woman-monster in Jane Eyre is the opposite of the other form of the dichotomy common in the traditional representation of women in Victorian writings as chaste, submissive and angelic in both male and female-authored texts.

This image of the madwoman, forced into non-conformity, violence, or even decadence, continued right into the twentieth century in the literary output of female writers, inspired by the feminist activism of the era. It represented their protest against such stereotypical female characters which they find degrading and illogical. Meanwhile, it reflects the anxiety of some of these writers and their attempt to accept the demands of the man-controlled world: the male's right to dominate women and women's passive subservience to men. According to Gilbert and Gubar (2000), Victorian women authors "dramatise their own self-division, their desire to both accept the structures of patriarchal society and to reject them."

However, the legacy of social injustice and oppression against women can be traced back to the eighteenth century in the representation of women in Restoration drama. Initially coined by the Restoration dramatist 
Nicholas Rowe (1674-1718), the term 'she-tragedy' refers to a particular trend in playwriting as the emphasis and interest of the playwrights shifted from heroic to social concerns (Note 1). The main reason behind the rise into popularity of the she-tragedy was the desire to satisfy the artistic taste of the restored King Charles II. The king lived in exile in France during Oliver Cromwell's Puritan supremacy. He was accustomed to seeing female roles played by actresses in French and Italian theaters (Note 2).

This kind of tragedy features a powerless female character as the protagonist and aims at arousing the spectators' sympathy with her hardships. The "victimization" and the "defenselessness" of the female characters are the main focus in the she-tragedy (Stewart, 2010). The tragic heroines sometimes commit a sin and struggle to evade its tragic consequences on their lives, but this transgressive act ultimately triggers their tragic downfall. The she-tragedies also explore the psychological pressures women experience in their domestic spheres and their reactions under stress. In these tragedies women are susceptible to different adversities and sinister events, such as sexual assault, madness, the death of loved ones - a husband or a child - mental disorder, and subsequent death or suicide, owing to their agony and despair.

Though no longer used nowadays, the term can be applied to modern plays that depict the social injustice and the plight of women in patriarchal societies. With the rise of feminist activism and the call for equality between men and women, feminist writers, including dramatists, protest the discrimination and cruelty against women. Even in America, a country proud of its dream of equality on all levels (gender is not an exception), women's position is not different from their sisters' marginalized role elsewhere.

\section{The Rebellion of the Female-as-angel Stereotype in Trifles}

Susan Glaspell was one of the American dramatists who devoted her plays to denounce the victimization and restrictions imposed on women. She portrays the dilemmas of her female protagonists and their endeavor to survive in their male-dominated society. Her female characters are victims of the patriarchal system and are entrapped by the society's predefined roles. While working as a journalist, Glaspell was commissioned to report a trial in Iowa in 1899 of a rural woman, Margaret Hossack, accused of killing her husband. Though the authorities initially found her innocent of the crime, she was subsequently found guilty and was sentenced for a lifetime imprisonment. Despite the fact that Glaspell was convinced of the vicious nature of Hossack's criminal act, she identified with her and decided to commemorate her experience in a one-act play, Trifles, that she wrote for her Provincetown Players theatrical company in 1917.

Linda Ben-Zvi, in “"Murder, She Wrote': The Genesis of Susan Glaspell's Trifles" (2002) comments on Glaspell's feminist purpose in probing the psychology of her female protagonist, Minnie Wright, her real-life counterpart and the impetus of their homicidal tendencies, saying:

Whether Margaret Hossack or Minnie Wright committed murder is moot; what is incontrovertible is the brutality of their lives, the lack of options they had to redress grievances or to escape abusive husbands, and the complete disregard of their plight by the courts and by society. Instead of arguing their innocence, Glaspell concretizes the conditions under which these women live and the circumstances that might cause them to kill.

Thus, based on these actual events, Trifles dramatizes the dark history of a farmer's wife, Minnie, who is accused of strangling her husband, John Wright. Through her presentation of an offstage female protagonist, a new technique for the time in which the play was performed, Glaspell attempts to study the motives that stimulate the wife to kill her husband. Jessica Bomarito and Jeffrey W. Hunter (2005) applaud Glaspell's use of this innovative technique, not only in Trifles, but also in other plays like Bernice (1919) and Alison's House (1930):

In this device lies a striking achievement: she brings the absent women onstage diegetically, while at the same time their absence serves as a commentary on the manner in which the patriarchy has deprived women of their substance. That these women appear only through the words of others speaks to the constructed nature of womanhood itself.

Gradually, and through the conversation between the two female characters in the play, Mrs. Hale, Minnie's neighbor, and Mrs. Peters, the Sheriff's wife, it is revealed that Minnie, is driven to kill her husband as a result of the hopelessness and desperation she feels because of her isolated and joyless life.

The characters, mainly the neighbors, the local attorney (George Henderson), and the sheriff (Henry Peters), investigate any evidence to see whether or not the wife is involved in the crime. The cold kitchen is the first sign that discloses the miserable life Minnie endures with her husband. The fact that Mrs. Hale and Mrs. Peters hesitate to enter the kitchen emphasizes their insight into Minnie's inescapable fate and the motives that drive her to kill John Wright. It also sets the tragic mood of the play, emblematic in this cold and dark atmosphere. The two women "stand close together near the door" as they enter and refuse to interact or open up to the male 
characters (Glaspell, 1987). This highlights the patriarchal nature of the community and the subordinate role women have in this society.

Meanwhile, Mrs. Hale, sympathetic with the suspected wife, decides to side with her own gender against the patronizing men. Even the circumspect, law-abiding Mrs. Peters, who is, as the attorney says "married to the law," being the sheriff's wife, and who has the conformist attitude that "the law is the law" and "the law has got to punish a crime," identifies with the off-stage protagonist (Glaspell, 1987). The women understand Minnie's predicament when they observe her untidy kitchen, the bread she left outside the box, the dirty table, and the uneven stitching of a piece of a quilt.

When the arrogant men start criticizing Minnie's inexperienced housekeeping and her dirty and messy kitchen, her friends come to her defense. Mrs. Hale defiantly justifies that "there's a great deal of work to be done on a farm" (Glaspell, 1987). She argues that Minnie should not care for cleaning a place where nobody visits to see the mess, a direct reference to Minnie's loneliness. That is why, the women are accused of being "loyal to [their] sex" (Glaspell, 1987). As Henderson investigates Minnie's cupboard closet, he finds a broken jar of fruit preserves. When Mrs. Peters defends Minnie, Lewis Hale taunts her, saying, "Well, women are used to worrying over trifles" (Glaspell, 1987).

The men's patronizing view and their humiliating comments on women and their world make Minnie's daily chores-her sewing, cleaning and baking and her life with her stern husband-more pathetic. As Mrs. Hale and Mrs. Peters privately discuss Minnie's hard life, they are happy that "the men couldn't hear [them]" (Glaspell, 1987). This reflects the conflict between the two sexes and the inability to bridge the wide gap between men and women in this phallocentric world.

Mrs. Hale remembers Minnie Foster's life in the past before marrying John Wright. Minnie was an amateur singer in the town's choir, and she was elegant, energetic and happy: "She used to wear pretty clothes and be lively, when she was Minnie Foster, one of the town girls singing in the choir" (Glaspell, 1987). When she became Mrs. Wright, her life with her careless husband turned into misery and despair. He was eccentric, quarrelsome, anti-social, and reticent and he suppressed all Minnie's wishes. "I don't think a place'd be any cheerfuller for John Wright's being in it," Mrs. Hale informs the attorney (Glaspell, 1987).

Furthermore, the Wright farmhouse is set back from the road, in a lonely, desolate area. It is a gloomy, cold house "down in a hollow," where no one comes to visit, and Minnie is kept busy so that she cannot socialize with others (Glaspell, 1987). John Wright even refuses his neighbor's, Mr. Hale's, offer to share a telephone line with him. This reflects his intention of keeping his wife away from any contact with the world outside his farm and his carelessness to his wife's needs. He spends most of his time working on the farm. Minnie is, thus, engulfed in this lonely place, having nobody to visit her to ease the tension caused by her protracted isolation. She is rendered 'mini' or trivial as her name metaphorically implies by an oppressive husband whose name, (W)right, ironically indicates the opposite.

Mrs. Hale reasons the whole matter as being the outcome of Minnie's disappointment and seclusion, intensified by her unhappy marital life. A miser, her husband does not buy her new attires to substitute her shabby clothes to be able to show herself in public occasions. As a result, Minnie does not find any solace neither in her husband's company nor in socializing with other people: "Wright was close. I think maybe that's why she kept so much to herself. She didn't even belong to the Ladies' Aid. I suppose she felt she couldn't do her part, and then you don't enjoy things when you feel shabby" (Glaspell, 1987).

The main clue to the crime the women are able to find is a broken cage and a dead canary in Mrs. Wright's sewing kit. They realize that John Wright kills Minnie's beloved, child-like pet to make his wife's life more lonely and miserable. The broken birdcage, Mrs. Peters finds in Minnie's kitchen cupboard, stands for Minnie's own bleak farmhouse. Minnie spends all her life in a cage-like home and, accused of killing her husband, she is now confined in a prison. The dead canary symbolizes her own dead, artistic "spirit and personality," as Minnie Foster, that is murdered by her husband, which Annette Kolodny views as "the essential crime" in the play (Cited in Aptheker, 1989).

Like Bertha Mason in Jane Eyre, Minnie is rendered into a life-in-death existence and is driven to the verge of insanity. Her murder of her husband is her revenge against the stifling patriarchal order that deprives her of the right to live a normal and a free life. Hence, Glaspell questions the institution of marriage and patriarchal authority that might lead desperate women into such homicidal acts, as Karen Alkalay-Gut (1995) opines: "Women, in the context of Trifles ... are trapped by a social system that may lead them into crime and punish them when they are forced to commit it." It is not Minnie's tragedy that is explored in the play, but all other oppressed women, living in similar situations. 
The men miss the clues to the murder because they are ignorant of women's domestic world and their psychology. They search for the clues upstairs and outside the house, believing that Minnie cannot hide the evidence in the kitchen. This highlights the clash between the two sexes, since the women are able to find these clues "through their attentiveness to the 'trifles' in her life, the kitchen things considered insignificant by the men" (Mael, 1989). The female characters prove their mental and emotional superiority over the men, as they not only empathize with Minnie, but they also choose to become Minnie's partners by hiding the clues to the crime from the men.

What motivates the two women to conceal the evidence from the murder investigators is mainly the men's sexism. They cannot condone the recurrent offenses of the men. It is also because they have experienced the same hardships Minnie suffers in her life, particularly loneliness and abjection. Their life is not easier or even more comfortable than Minnie's. Their decision to protect Minnie is not only an expression of their sisterly solidarity, but it is also their retaliation against the unjust society that abuses them: "Wouldn't they [the men] just laugh! Getting all stirred up over a little thing like a-dead canary" (Glaspell, 1987). Linda Ben-Zvi (2005) finds in Glaspell's portrayal of this emotional bond among women as "the potential for female action and the usurpation of power. By having the women assume the central positions and conduct the investigation and the trial, she actualizes an empowerment that suggests that there are options short of murder that can be imagined for women." Similarly, Liza Maeve Nelligan (1995) states that Glaspell "dramatizes the powerful sense of solidarity women shared and assumes that this solidarity was somehow responsible for superior female morality."

Women's victory is manifested by the development of the timid Mrs. Peters, who grows into a three dimensional character as she realizes the absurdity of conformity into the established patriarchal order and the need to move into action before it is too late for her and other women. Glaspell directs the audiences' sympathy with her female protagonist, who is viewed and treated as a criminal by the society and the legal institution. Instead, she depicts her as a victim, emblematic of all women who suffer from patriarchal oppression and who are forced into loveless marriages with cruel and dominant husbands like John Wright.

Like the traditional she-tragic heroines, Minnie falls prey to exploitation and her lonely life on the farm for more than thirty years puts her in a status similar to that of the imprisoned damsels in gothic stories. Though her husband is not as cruel as the villains in Gothic literature, he is mainly responsible for her misery and psychological disintegration. Her life in the prison, if she is to be found guilty by the authorities, would not be as difficult as her life with Mr. Wright in his isolated farmhouse. Her revolt against the male-defined norms of the woman-as-angel stereotype is her last hope to move out of the attic.

\section{The Destructive Female Character in The Verge}

In The Verge (1921), Glaspell denounces the limitations that render women helpless in modern times. Women were expected to be dutiful wives and mothers, and not to have additional roles outside the home. The Verge reflects Glaspell's dissatisfaction with the way women were treated by the patriarchal system with limited roles and opportunities. According to Arthur Waterman (1979), "The Verge is a remarkable achievement, one that in its attitude toward woman's identity is far ahead of almost any other play written in the next decades or so."

The critical weight on The Verge is devoted to the study of the significance of the protagonist's innovative language as a vital means in feminist discourse and the inefficiency of traditional language in liberating women from the social strictures that confine them (Note 3). It also focuses on Glaspell's role "as a female playwright experimenting with gender, language and invention in a patriarchal culture" (Galbus, 2000).

In spite of the emergence of the so-called 'New Woman' and the 'flappers'-defiant, fashionable women, smoking and drinking in public and wearing less diffident clothes than the Victorian heavy dress styles-women were expected to behave according to the established Victorian moral code. The First World War was an opportunity for many American women to get out of the domestic sphere and join the workforce to fill the vacuum left by the men-soldiers who were fighting abroad. This brought financial independence for many women. But it did not contribute to the fulfillment of their dream of gender equality and freedom, as they still suffered from oppression and maltreatment. After the end of the war, the society expected women to perform their traditional duties as homemakers and thwarted their dreams of attaining equal rights. Unable to resist this patriarchal order, many women became victims of depression and derangement and were subjected to sanitarium treatment (Heilmann, 2004).

The title, The Verge, reflects the female protagonist's, Claire Archer's, mental state as she is trapped in a situation that slowly pushes her into lunacy. Claire can be classified as one of Colin Wilson's outsider's that he listed in his seminal book, The Outsider (1956). This is mainly because she cannot adjust to the societal conventions and she resists restriction of any kind. Waterman (1979) similarly describes her as "a pariah because she is different 
as a woman, a person, and a biologist, and there is no room in the "normal' world for her difference." Claire is a 'New Woman' who struggles against the stereotypical role of women as devoted wives and mothers. She refuses to be intimidated by any man or woman, advising her against being "unnatural" (Glaspell, 1987).

Claire busies herself with her botanical experiments in her greenhouse. Yet, the success of her experiments in creating new, hybrid plants does not please her. Her dissatisfaction with her life and her rebellious nature ruin her household and drive her to be a destructive woman. What makes her a she-tragic figure is not only her personal flaws, but the society's mores that demand her to be a conformist. Claire's attempt to break free from the domestic and social yoke is obvious in her opinion: "We need not be held in forms molded for us. There is outness - and otherness" (Glaspell, 1987).

Claire's miserable life is symbolically embodied in her inability to communicate with the people around her, apparent in her fragmentary and intermittent speeches. When she fails to express her inner turmoil, she resorts to poetry as her means of addressing the sexist world that fails to understand her desperate situation and that denies her the womanly identity she longs for:

Perhaps the madness that gave you birth will burst again,

And from the prison that is you will leap pent queerness

To make a form that hasn't been-

To make a person new.

And this we call creation. (Glaspell, 1987)

Her dreams are thwarted by the men and women who surround her, most of whom expect Claire to behave according to the established social norms (Note 4). Claire's husband, Harry Archer, keeps reminding her of the proper social manners exhibited by refined women. Though he does not object to his wife's untraditional scientific experiments - a thing that is too abnormal for the time - he abhors her excessive interest in her work, viewing this obsession as an absurd effort: "Well, I don't want to see it get you-it's not important enough for that" (Glaspell, 1987). He also instructs her how to be a "decent," and an obedient woman. Seeing his wife's inadequate behavior, he believes that she is mentally ill and needs to see a psychiatrist. Harry, then, informs Claire that he has invited Dr. Emmons, the neurologist, to dinner in hopes that he can make her well. As a result, Claire hysterically asks Tom Edgeworthy, one of her admirers, that she is in trouble and needs help.

Claire does not love Elizabeth, her daughter from her first marriage, though the latter tries her best to win her mother's heart and to be close to her. Her sister, Adelaide, an archetypal image of the responsible mother and wife, advises Claire how to be a good mother to Elizabeth and she disapproves of her abnormality and recklessness as a married woman. She encourages her to be as devoted to her family as she is herself: "free, busy, happy. Among people, I have no time to think of myself" (Glaspell, 1987). But Claire ignores Adelaide's advice and considers it as an attempt to bring her back into the same labyrinthine, patriarchal domain. She believes that Adelaide is a passive, compliant woman who sticks "in one place because she hasn't the energy to go anywhere else" and does not have the will and dream to be free and independent (Glaspell, 1987).

Claire's rejection of her daughter represents the feminist's view of the maternal role as a burden. It is also triggered by her belief that Elizabeth, like her aunt Adelaide who has raised her and is a surrogate mother for her, is the epitome of conformity that keeps women constrained by the traditional gender roles dictated by the society. Veronica Makowsky (1993) explores this new maternal image in Glaspell's The Verge, noting that

The protagonist of Glaspell's The Verge, Claire Archer, is not interested in mothering her conventional debutante daughter. Instead Claire wishes to experiment with plants to create new and bolder life forms and keep her plants, and her life, on the risky but exciting 'verge'.... This is a pioneering, radical, adventuresome maternity, not the lulling comfort that we often associate with the term. Claire Archer's maternity represents Glaspell's views taken to their extremes.

Claire strives to break the established conventions of her stagnant society, which she describes as patterns: "I want to break it up! If it were all in pieces, we'd be shocked to aliveness" (Glaspell, 1987). Through her botanical experiments, Claire dreams of creating something new and original, different from the patterns that are enforced by the community, and which women are obliged to follow. But her endeavors are not without obstacles, a thing illustrated by the patterns that the frost forms on the greenhouse and Claire's struggle to protect her new horticultural samples from the threatening cold weather outside. The ominous atmosphere of the play is additionally exemplified by another threatening power, a wind, raging outside and forming "patterns of sound" (Glaspell, 1987). These menacing natural elements that threaten the preserved plants run line in line with the 
protagonist's struggle to forge an identity of herself.

The other aspect that makes Claire a she-tragic character is her infidelity to her husband. She does not object to having extra-marital affairs with both Tom and Dick, the family's friends who are romantically involved with her. What makes her a pathetic figure is that she is not interested in these men as physical objects, but as a means to help her to find an outlet out of her misery. Her realization that all men are the same is what stimulates her to shoot Tom at the end.

Claire's failure in breaking free from her traditional role gradually drives her into depression. She ultimately fails to live up to her dreams. As she becomes increasingly agitated and nervous over her unbearable situation, she realizes that only in violence one can find rest. That is why, she tries to harm her daughter, destroys her experiments, kills Tom, and shatters the greenhouse when she shoots the gun through the roof. Her violence against her precious plants and the people she inwardly loves represents her revolt against these patterns that stifle her. It also marks the beginning of her mental decline: "Stop doing that! — words going into patterns; ... Thoughts take pattern — then pattern is the thing" (Glaspell, 1987).

The success of an experiment with one of her plants, which she calls the Breath of Life and which symbolically stands for her longing to change the long-held social patterns, does not bring her any delight or satisfaction. Her frustration is so intense that she cannot but grow more and more destructive. The way she eventually destroys her plants mirrors her dissatisfaction with her life and the patronizing view men have over her. Claire loses control at the end and succumbs to her mental disintegration. She kills Tom because she believes that he, like all the other men, tries to possess her and tame her rebellious spirit, especially when he tells her: "You are mine, and you will stay with me! You hear me? You will stay with me!" (Glaspell, 1987). Jessica Bomarito and Jeffrey W. Hunter (2005), overlooking the tragic end of the protagonist, view in Claire's strangling of Tom a feminist fulfillment and the act of murder a symbolic one:

Glaspell is not, of course, sanctioning murder; the act must be read symbolically. Only by daring to break the confines of the patriarchy, confines that may come disguised as the love that wishes to keep one "safe," can women imagine and create new ways of being.

Unlike Henrik Ibsen's Nora Hellmer, the female protagonist in A Doll's House, who is able to defy the society and liberate herself from her domestic prison, Glaspell's Claire is a she-tragic figure who becomes a victim of insanity and is to be delivered to another prison-like residence - the asylum. Like Minnie Wright she lives in a vicious circle of patriarchal authority and ends up institutionalized for mental problems. Claire contemplates death as a salvation for her unbearable situation, a solution that, according to her, women should favorably welcome: "Why should we mind lying under the earth?" (Glaspell, 1987). Nevertheless, she finds relief in her tragic fate, viewing it as being superior to her passive role, as she ultimately declares: "Madness that is the only chance for sanity" (Glaspell, 1987). Like Bertha Mason, she represents the female-as-monster, the rebellious eve that rejects stereotyping and move out of her domestic prison, despite her status as a she-tragic character.

\section{Conclusion}

Susan Glaspell employs her drama as a means of protest, objecting to the marginal image of women in her society. She presents tragic figures, who though untraditionally do not die at the end, but still are great sufferers. Glaspell's she-tragic heroines are encouraged to act because of the unbearable situations they face in their patriarchal society. Confined and oppressed by the male-controlled system, they suffer intense psychological pressure, and thus, react violently. In spite of their violent reactions, Glaspell's protagonists are not innately criminals. What drives them to kill is their frustration and sense of entrapment. Their attempts to break free from their cage-like domestic restraints only lead them into other forms of imprisonment - the institutional prison and the mental asylum. They resist stereotyping; especially the society's expectations of women to be what Gilbert and Gubar call 'the female-as angel' stereotype. Glaspell's portrayal of she-tragic characters makes her the mouthpiece of all oppressed women not only in the United States but also everywhere and at anytime.

\section{Notes.}

Note 1. Notable examples on these plays include Thomas Otway's The Orphan (1680), John Banks'Virtue Betrayed, or, Anna Bullen (1682), Thomas Southerne's The Fatal Marriage (1694) and Nicholas Rowe's The Fair Penitent (1703) and Lady Jane Grey (1715).

Note 2. Before the emergence of the she-tragedy, female roles were mainly played by young male actors. Actresses were not socially accepted because women were not expected to be seen in public places. Thus, the shift moved from the heroes to heroines, and drama was no longer male-centered (For more details see Marsden, 2002). 
Note 3. The Verge also demonstrates Sigmund Freud's theories of psychoanalysis that were popular in the United States at the beginning of the twentieth century.

Note 4. The Parisian feminist activist, Simon de Beauvoir, in her The Second Sex (1989), voiced her dissatisfaction with the androcentric social system that treats women as a "second sex," marginalized and so dependent on men. According to her, women are defined as "the other" and are ostracized if they try to defy the established patriarchal order. Even their success is viewed as a kind of deviation from the norm.

\section{References}

Alkalay-Gut, K. (1995). Murder and marriage: Another look at Trifles. In L. Ben-Zvi (Ed.), Susan Glaspell: Essays on her theater and fiction (pp. 71-81). Ann Arbor, Michigan: University of Michigan Press.

Aptheker, B. (1989). Tapestries of life: Women's work, women's consciousness, and the meaning of daily experience. Amherst, Massachusetts: University of Massachusetts Press.

Ben-Zvi, L. (1995). 'Murder, she wrote': The genesis of Susan Glaspell's Trifles. In L. Ben-Zvi (Ed.), Susan Glaspell: Essays on her theater and fiction (pp. 19-49). Ann Arbor, Michigan: University of Michigan Press.

Ben-Zvi, L. (2005). Susan Glaspell: Her life and times. Oxford: Oxford University Press.

Bomarito, J., \& Hunter, J. W. (2005). Feminism in literature: A Gale critical companion, volume 4: 20th century, topics. Farmington Hills, MI: Thomson Gale.

de Beauvoir, S. (1989). The second sex. New York: Vintage.

Galbus, J. (2000). Susan Glaspell's The Verge: A Socratic quest to reinvent form and escape Plato's cave. Journal of Dramatic Theory and Criticism, 15(1), 81-95.

Gilbert, S. M., \& Gubar, S. (2000). The madwoman in the attic: The woman writer and the nineteenth-century literary imagination (2nd ed.). New Haven, Conn.: Yale University Press.

Glaspell, S. (1987). Plays by Susan Glaspell. Cambridge: Cambridge University Press. https://doi.org/10.1017/CBO9781139165969

Heilmann, A. (2004). New woman strategies: Sarah Grand, Olive Schreiner, and Mona Caird. Manchester: Manchester University Press.

Mael, P. (1989). Trifles: The path to sisterhood. Literature/Film Quarterly, 17(4), 281-284.

Makowsky, V. (1993). Susan Glaspell's century of American women: A critical interpretation of her work. Oxford: Oxford University Press. https://doi.org/10.1093/acprof:oso/9780195078664.001.0001

Marsden, J. I. (2002). Tragedy and varieties of serious drama. In S. J. Owen (Ed.), A companion to Restoration drama (pp. 228-242). Hoboken, New Jersey: Blackwells.

Nelligan, L. M. (1995). The haunting beauty from the life we've left: A contextual reading of Trifles and The Verge. In L. Ben-Zvi (Ed.), Susan Glaspell: Essays on her theater and fiction (pp. 85-104). Ann Arbor, Michigan: University of Michigan Press.

Stewart, A. M. (2010). The ravishing Restoration: Aphra Behn, violence, and comedy. Pennsylvania: Susquehanna University Press.

Waterman, A. (1979). Susan Glaspell's The Verge: An experiment in feminism. Great Lakes Review: A Journal of Midwest Culture, 6(1), 17-23. https://doi.org/10.2307/20172470

Wilson, C. (2001). The outsider (2nd ed.). London: Phoenix.

\section{Copyrights}

Copyright for this article is retained by the author, with first publication rights granted to the journal.

This is an open-access article distributed under the terms and conditions of the Creative Commons Attribution license (http://creativecommons.org/licenses/by/4.0/). 